\title{
HUBUNGAN PENGETAHUAN TERHADAP MANAJEMEN DIRI PADA PENDERITA PENYAKIT JANTUNG KORONER
}

\author{
Devi Susanti ${ }^{1 *}$, Lastriyanti ${ }^{2}$, Sugeng Haryono ${ }^{3}$ \\ 1. Program Studi DIII Keperawatan, STIKes Mitra Keluarga, Bekasi-Indonesia \\ 2. Program Studi S1 Keperawatan, STIKes Mitra Keluarga, Bekasi-Indonesia \\ 3. Departemen Keperawatan Medikal Bedah, Akademi Keperawatan Hang Tuah, Jakarta-Indonesia
}

*Korespondensi: Devi Susanti | STIKes Mitra Keluarga | devisusantik715@gmail.com

\begin{abstract}
Abstrak
Pendahuluan: Penyakit Jantung Koroner (PJK) adalah penyakit "silent killer" yang menyebabkan kematian mendadak. Penderita PJK akan mengalami serangan berulang dan akan menimbulkan dampak re -hospitalisasi bagi aspek fisik, psikologis, sosial dan ekonomi. Tujuan dari penelitian ini adalah untuk mengetahui hubungan pengetahuan terhadap manajemen diri penderita PJK di RSAL Dr. Mintohardjo Jakarta.

Metode: Metode yang digunakan studi korelasi yaitu menganalisis hubungan tingkat pengetahuan dengan manajemen diri penderita PJK dengan rancangan cross sectional yaitu jenis penelitian yang menekankan waktu pengukuran data variabel independen dan dependen. Subjek adalah pasien PJK di poli jantung RSAL Dr. Mintohardjo Jakarta dengan teknik non probability sampling jenis consecutive sampling dengan 95 responden. Alat ukur menggunakan kuesioner data karakteristik, pengetahuan dan manajemen diri.

Hasil: Hasil penelitian bivariat bahwa $35,8 \%$ penderita PJK memiliki pengetahuan baik dan manajemen diri yang baik pula. Uji korelasi menggunakan Chi square dengan nilai $p$ value 0,551 . Nilai $\mathrm{p}>\alpha 0,05$ yang artinya tidak terdapat hubungan yang signifikan antara pengetahuan dengan manajemen diri penderita PJK.

Kesimpulan: Kesimpulan penelitian ini adalah walaupun secara statistik tidak ada hubungan antara pengetahuan dengan manajemen diri, data pengamatan menunjukkan terdapat peningkatan manajemen diri ketika berpengetahuan baik dimana mungkin ada faktor lain yang lebih berpengaruh.
\end{abstract}

Kata Kunci: Manajemen diri, Pengetahuan, Penyakit Jantung Koroner.

Diterima 27 Oktober 2019; Accepted 30 Desember 2019

\section{PENDAHULUAN}

Penyakit Jantung Koroner (PJK) adalah salah satu penyakit yang menggangu sistem kardiovaskuler dimana diakibatkan oleh adanya penyempitan pada pembuluh darah koroner yang disebabkan oleh adanya plak aterosklerosis ataupun spasme (Majid, 2007). PJK adalah penyakit yang "silent killer" dimana dapat menyebabkan terjadinya kematian mendadak. Penyakit ini merupakan permasalan kesehatan di dunia yang dapat menyerang siapa saja.

Angka kejadian kesakitan dan kematian yang dapat ditimbulkan akibat PJK cukup tinggi. Hal ini dibuktikan dari data WHO (2015) yang menunjukkan sekitar 14,1 juta penduduk dunia meninggal akibat penyakit kardiovaskular pada tahun 2002 (mewakili 31\% kematian di dunia), terdiri dari 7,4 juta akibat PJK dan 6,7 juta akibat stroke. PJK terjadi di negara dengan penghasilan rendah sampai dengan menengah sebanyak $80 \%$ dan diperkirakan sebanyak $37 \%$ penduduk dunia akan meninggal akibat penyakit kardiovaskuler. Penyakit kardiovaskuler merupakan masalah kesehatan utama di Indonesia. Hal ini dibuktikan dari hasil data Riskesdas Tahun 2013 menunjukkan terdapat peningkatan prevalensi hipertensi dari 7,6\% pada tahun 2007 menjadi 9,5\% pada Tahun 2013. Selain itu data Riskesdas tahun 2013 menunjukkan prevalensi penyakit jantung koroner dan gagal jantung terlihat meningkat dari tahun ke tahun seiring dengan peningkatan umur penderita. Berdasarkan data tiga bulan terakhir (Juni sampai dengan Agustus 2017) terdapat 1.353 pasien dengan penyakit jantung koroner dari 3.228 orang pasien yang datang berobat di poli Rumah Sakit Angkatan Laut Dr. Mintohardjo Jakarta.

Penyakit jantung koroner terjadi secara tiba - tiba dan membutuhkan penanganan secara farmakologis maupun elektif. Hal ini membutuhkan biaya yang sangat besar untuk pengobatan dan tindakan kateterisasi serta perawatan di Rumah Sakit. Berbagai dampak yang diuraikan diatas dapat dihindari apabila penderita PJK mampu melakukan adaptasi dengan dirinya dalam melakukan manajemen diri. Hal ini diper lukan agar penderita PJK tidak mengalami serangan jantung berulang.

Penderita PJK diharapkan mampu menerapkan manajemen diri yang optimal dalam aktivitas, 
stress, pengobatan, maupun diet untuk dapat memperoleh kualitas hidup yang baik dengan pola hidup yang sehat. Manajemen diri adalah hubungan antara individu dalam aktifitas dan praktik untuk mempertahankan dan meningkatkan kesehatan (Selvey, 2008). Perawat berperan dalam memberikan edukasi atau pengetahuan pada penderita dengan PJK agar penderita mampu melakukan manajemen dirinya agar terhindar dari kejadian serangan jantung berulang. Pengetahuan merupakan hasil dari pengideraan manusia terhadap suatu objek melalui indra yang dimilikinya (Notoadmojo, 2010).

Apabila kejadian serangan jantung berulang dapat dikendalikan maka dapat meminimalkan terjadinya re-hospitalisasi dan beban re-hospitalisasi. Tindakan keperawatan yang dapat dilakukan oleh perawat adalah melalui tindakan pendidikan kesehatan perihal manajemen diri faktor risiko yang dapat dimodifikasi. Hal ini akan dapat membantu penderita dalam memodifikasi pola hidupnya melalui discharge planning sebelum penderita pulang ke rumahnya.

\section{METODE}

Penelitian ini merupakan penelitian analitik deskriptif dengan menggunakan desain cross sectional yang dapat diartikan bahwa peneliti melakukan pengukuran atau penelitian dalam satu waktu. Peneliti menggunakan pendekatan cross sectional karena penelitian ini bermaksud mengidentifikasi ada tidaknya hubungan berbagai variable independen terhadap variable dependen dalam satu kali pengukuran menggunakan alat kuesioner. Penelitian ini dilakukan di poli jantung RSAL Rs.Mintohardjo Jakarta dengan jumlah responden penelitian sebanyak 95 responden.

Kriteria inklusi responden adalah penderita penyakit jantung koroner berdasarkan rekam medis (diagnosa medis), yakni pasien dengan ST-Elevation Miocard Infarct (STEMI), Non ST-Elevation Miocard Infarct (NSTEMI), Unstable Angina Pectoris (UAP); tidak mengalami sesak atau nyeri dada; dan bersedia menjadi responden penelitian. Rumus yang digunakan untuk perhitungan sample penelitian adalah rumus Slovin.

Penelitian dilakukan selama dua minggu di poli jantung RSAL Dr.Mintohardjo. Peneliti mengirimkan surat ijin penelitian kepada direktur dan koordinator poli jantung RSAL Dr.Mintohardjo Jakarta. Setelah mendapatkan ijin penelitian, peneliti melihat status rekam medis untuk memilih kriteria responden sesuai kriteria inklusi penelitian. Setelah itu peneliti mengobservasi kondisi pasien apakah memenuhi kriteria inklusi penelitian. Peneliti menjelaskan dengan memberikan lembar penjelasan penelitian terkait tujuan dilakukan penelitian. Kemudian, peneliti memberikan lembar persetujuan penelitian apabila pasien bersedia menjadi responden. Setelah itu, peneliti menjelaskan semua item pertanyaan yang ada didalam kuesioner, sehingga memudahkan responden dalam menjawab pertanyaan.

\section{HASIL}

\section{Hasil analisis univariat}

Tabel 1 : Distribusi frekuensi tingkat pengetahuan penderita penyakit jantung koroner

\begin{tabular}{|c|c|c|c|}
\hline No & Pengetahuan & Frekuensi & Persentasi (\%) \\
\hline 1 & Baik & 65 & 54,7 \\
\hline 2 & Baik & 30 & 45,3 \\
\hline & Total & 95 & 100 \\
\hline
\end{tabular}

Sumber : data primer diolah berdasarkan data yang diperoleh

Pada tabel 1 diatas menggambarkan bahwa sebagian besar penderita penyakit jantung koroner sebanyak 54,7 \% (65 responden) memiliki pengetahuan yang baik mengenai penyakit jantung koroner.

Tabel 2 : Distribusi Frekuensi manajemen diri penderita penyakit jantung koroner

\begin{tabular}{|c|c|c|c|}
\hline No & Manajemen Diri & Frekuensi & Persentasi (\%) \\
\hline 1 & Baik & 50 & 52,6 \\
\hline 2 & $<$ Baik & 45 & 47,4 \\
\hline & Total & 95 & 100 \\
\hline
\end{tabular}

Sumber : data primer diolah berdasarkan data yang diperoleh

Pada tabel 2 diatas menunjukkan bahwa sebagian besar penderita penyakit jantung koroner 52,6\% (50 
responden) memiliki manajemen diri yang baik.

\section{Hasil analisis bivariat}

Hubungan pengetahuan dengan manajemen diri penderita penyakit jantung coroner

Tabel 3: Hubungan pengetahuan dengan manajemen diri penderita penyakit jantung koroner

\begin{tabular}{|c|c|c|c|c|c|c|c|}
\hline \multirow{2}{*}{ No } & \multirow{3}{*}{ Pengetahuan } & \multicolumn{4}{|c|}{ Manajemen Diri } & \multicolumn{2}{|c|}{ Total } \\
\cline { 3 - 8 } & & \multicolumn{2}{|c|}{ Baik } & \multicolumn{2}{|c|}{ Kurang Baik } & \multicolumn{2}{|c|}{} \\
\cline { 3 - 8 } & & F & \% & F & \% & F & \% \\
\hline 1. & Baik & 34 & 35,8 & 31 & 32,6 & 65 & 68,4 \\
\hline 2. & < Baik & 16 & 16,8 & 14 & 14,8 & 30 & 31,6 \\
\hline & Total & 50 & 52,6 & 45 & 47,4 & 95 & 100 \\
\hline
\end{tabular}

Tabel 3 menunjukkan bahwa sebagian besar penderita penyakit jantung koroner sebanyak 35,8\% memiliki pengetahuan baik sehingga manajemen diri yang baik pula. Uji korelasi menggunakan chi square dengan nilai $p$ value 0,551 . Nilai $\mathrm{p}>\alpha 0,05$ yang artinya adalah tidak terdapat hubungan yang signifikan antara pengetahuan dengan manajemen diri penderita penyakit jantung koroner.

\section{PEMBAHASAN}

\section{Pengetahuan}

Hasil penelitian ini menunjukkan bahwa sebagian besar penderita penyakit jantung koroner sebanyak 54,7 \% (65 responden) memiliki pengetahuan yang baik mengenai penyakit jantung koroner. Pengetahuan merupakan hasil dari pengideraan manusia terhadap suatu objek melalui indra yang dimilikinya (Not oadmojo, 2010). Intensitas perhatian dan persepsi terhadap objek sangat mempengaruhi pengetahuan.

\section{Manajemen diri}

Hasil penelitian ini menunjukkan bahwa sebagian besar penderita penyakit jantung koroner 52,6\% (50 responden) memiliki manajemen diri yang baik. Hal ini menunjukkan responden telah mampu menerapkan perilaku positif dalam mengatasi masalah penyakit jantung koronernya. Hal ini sejalan dengan pengetahuan yang baik yang dimiliki oleh sebagian responden penelitian ini

\section{Hubungan pengetahuan dengan manajemen diri penderita penyakit jantung koroner}

Hasil penelitian ini menunjukkan bahwa sebagian besar penderita penyakit jantung koroner sebanyak 35,8\% memiliki pengetahuan baik sehingga manajemen diri yang baik pula. Walaupun hasil uji secara statistik dengan korelasi chi square menunjukkan hasil sebaliknya yakni tidak terdapat hubungan yang signifikan antara pengetahuan dengan manajemen diri. Hal ini terjadi karena manajemen diri seseorang dapat dipengaruhi oleh faktor - faktor yang lain seperti lingkungan dan budaya. Menurut Saputri, et al (2014) faktor yang dapat mempengaruhi perilaku manajemen hipertensi adalah pengetahuan, lingkungan kejenuhan, budaya dan tidak terbiasa. Perilaku untuk sarana dan prasarana yang akan mempengaruhi perilaku seseorang. Hal ini sejalan dengan penelitian Mubarak (2011) dalam Ayu (2013) bahwa perilaku kesehatan akan terbentuk apabila didukung dari tiga faktor yakni faktor predisposisi, pendukung dan pendorong. Faktor predisposisi meliputi pengetahuan, sikap, kepercayaaan, keyakinan dan lain- lain. Faktor pendukung yaitu tersedianya atau tidak tersedianya fasilitas atau sarana kesehatan seperti puskesmas, obat-obatan dan sebagainya. Faktor pendorong adalah sikap dan perilaku petugas kesehatan maupun tokoh atau kelompok yang dijadikan contoh perilaku oleh masyarakat.

Pengetahuan dapat menjadi dasar dalam berperilaku, sehingga perilaku dapat bertahan lebih lama. Hal ini sejalan dengan Notoatmodjo (2007) yang menyatakan bahwa pengetahuan merupakan domain yang penting dalam terbentuknya perilaku seseorang. Apabila perubahan perilaku didasari dengan pengetahuan dan sikap yang positif maka yang menyebabkan perilaku yang bertahan lebih lama. Perubahan perilaku seseorang dalam manajemen diri tidak selalu diiringi dengan meningkatnya pengetahuan. Menurut Laraeni, et al (2015) yang menyatakan bahwa perilaku sangat berhubungan 
dengan pengetahuan namun peningkatan pengetahuan tidak selalu menyebabkan perubahan perilaku. Hal ini sejalan dengan hasil penelitian bahwa tidak ada hubungan yang signifikan antara pengetahuan dengan manajemen diri responden.

Perilaku responden untuk melakukan manajemen diri berupa aktivitas fisik seperti berjalan kaki selama 15 sampai 30 menit, konsumsi rendah lemak, kontrol tekanan darah, kolesterol darah, minum obat secara teratur, berhenti merokok serta manajemen stress merupakan kebiaasaan yang sudah sering mereka lakukan sejak lama dan menjadikan mereka terbiasa untuk melakukan aktivitas tersebut. Mardiyanti (2009) dalam Kusumastuti (2014) menyatakan bahwa perilaku berkaitan dengan kebiasaan. Kebiasaan tersebut akan mempengaruhi perilaku responden dalam manajemen diri. Kebiasaan responden dalam perilaku manajemen diri penyakit jantung koroner yang baik tidak harus memiliki sarana dan prasarana yanga memadai, cukup dengan berjalan kaki dan mengkonsumsi sayur dan buah-buahan yang baik untuk kesehatan jantung. Hal ini sejalan dengan Qudsiyah,et al (2015) yang mengemukakan bahwa sarana dan prasarana merupakan faktor pendukung terjadinya perubahan perilaku, namun yang paling dominan adalah faktor kebiasaan.

\section{KESIMPULAN}

Berdasarkan hasil penelitian ini dapat disimpulkan bahwa tidak ada hubungan pengetahuan terhadap manajemen diri penderita penyakit jantung koroner. Implikasi keperawatan yang dapat dilakukan dari hasil penelitian ini adalah dapat menjadi dasar penelitian selanjutnya berkaitan faktor lain yang dapat mempengaruhi manajemen diri penderita penyakit jantung koroner. Pendidikan kesehatan merupakan intervensi keperawatan yang dapat diberikan kepada penderita penyakit jantung coroner karena berdasarkan hasil pengamatan dalam penelitian, pengetahuan yang baik akan menjadikan manajemen diri baik pula.

\section{UCAPAN TERIMA KASIH}

Penelitian ini mendapat support dana dari Kemenristekdikti.

\section{REFERENSI}

Ayu, M. (2013). Hubungan pengetahuan dan sikap dengan perilaku kesehatan reproduksi pada remaja putri di SMA 5 Banda Aceh. Banda Aceh : Sekolah Tinggi Ilmu Kesehatan U'Budiyah.

Kusumastuti, D.I (2014). Hubungan pengetahuan dengan kepatuhan diet hipertensi pada lansia yang mengalami hipertensi di Panti Werdha Dharma Bakti Kasih Surakarta. Surakarta: STIKES Kusuma Husada. diakses pada 09 April 2018.

Laraeni, Y., Sofiyatin, R., \& Rahayu, Y. (2015). Hubungan Tingkat Pengetahuan, Sikap, dan Perilaku Ibu Terhadap Konsumsi Zat Gizi (Energi, Protein) pada Balita Gizi Kurang di Desa Labuhan Lombok. Media Bina Ilmih15. 9(1). Diakses pada 09 April 2018.

Majid, Abdul. (2007). Penyakit jantung koroner: patofisiologi, pencegahan, dan pengobatan terkini. eUSU repository Universitas Sumatera Utara. h.1-54.

Notoatmodjo, S. (2007). Promosi Kesehatan dan Ilmu Perilaku. Jakarta: Rineka Cipta.

Notoatmodjo, S. (2010). Ilmu Perilaku Kesehatan. Jakarta: Rineka Cipta.

Qudsiyah, W.A.,Pujiati, R.S.,\& ningrum, P.T. (2015). Faktor - faktor yang berhubungan dengan tingginya angka open defecation (OD) di kabupaten Jember (Studi di Desa Sumber Kalong Kecamatan Kalisat). E-Journal Pustaka Kesehatan, 3(2). diakses pada 09 April 2018.

Saputri, Y.S.,Muhlisin,A.,Budinugroho,A. (2014). Pengaruh pendidikan kesehatan terhadap pengetahuan dan kepatuhan diet hipertensi pada lanjut usia di Desa Wironanggan Kecamatan Gatak Sukoharjo. Surakarta: Universitas Muhammadiyah Surakarta. diakses pada 09 April 2018.

Selvey, L. (2008). Framework for self management 2008-2015. Queensland Health. May 62015. http://www.health.qld.gov.au/chronicdisease/document/fw2008to15.fullpdf.

World Health Organization. (2015). Cardiovasculer disease (CVDs). Retrieved March 6, 2015, from http://www.who.int/mediacentre/factsheets/fs317/en 